\title{
ON THE SEASONAL ABUNDANCE OF YOUNG FISH. VII. THE YEAR I939, JANUARY TO AUGUST
}

\author{
By F. S. Russell, F.R.S.
}

Naturalist at the Plymouth Laboratory

(Text-figs. I-4)

In a number of previous reports observations on the seasonal abundance of the pelagic young of teleostean fish in the plankton off Plymouth have been recorded for the years 1924 to 1938 inclusive. Owing to the outbreak of war the series for the year 1939 is unfortunately not complete. Collections were, however, made until the last week in August. Previous records have always shown that the numbers of young fish caught in the last four months of the year, September to December, are insignificant and in consequence it is

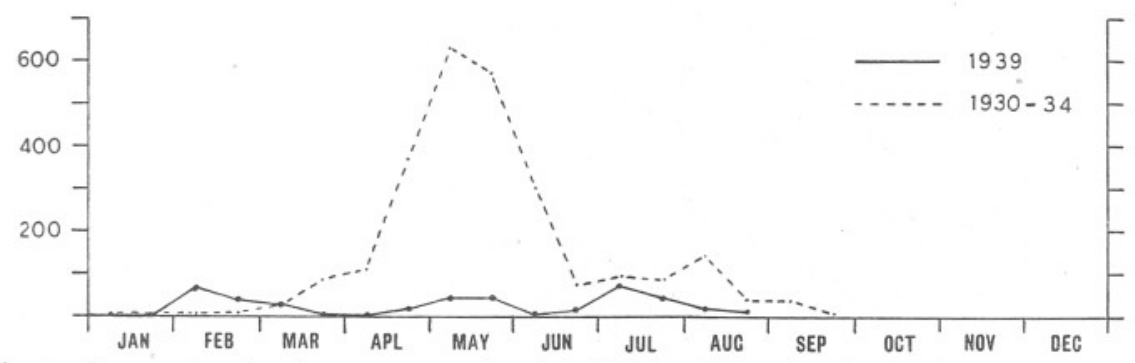

Fig. I. Curves showing the average catches in half-hour oblique hauls with the $2 \mathrm{~m}$. ringtrawl for each fortnight for all young fish, excluding clupeids, in 1939 ( - and the same averaged over the period 1930-4 inclusive (----).

desirable that the results for 1939 should be published since they cover fully the period of production of almost all species of fish. It is, also, essential that these records should not be lost as the year 1939 has been the worst yet recorded and sets a new low limit to the production of fish. It is much to be deplored that the sequence of observations may be broken, so that we may never know what point the trough of the decline may reach.

The results are published in the same form as in previous reports. The dates on which collections were made with the $2 \mathrm{~m}$. stramin ringtrawl are given in Table I, and the monthly average catches of the young fish per half-hour oblique haul in Table II. In Fig. $I^{\star}$ is given the curve for the average catches for each fortnight of all young fish, excluding clupeids, and

* In the corresponding Fig. I for I938 in Russell, I939, p. 38I, the point for the second fortnight in June was omitted from the curve for $1930-4$ in error. 
superimposed upon this the corresponding curve for the average catches over the period $1930-4$ inclusive.

The results show a complete absence of the peak for the young of spring spawners and a disastrous state of affairs in general. The sum of the monthly average catches of those post-larvae which show maximal abundance in the months June to October inclusive, excluding clupeids, was 57 in 1939, as against I35, I74 and II4 in 1938, I937 and 1936 respectively. If records had continued to the end of the year this figure might have been slightly higher, but in the light of the results for previous years it is doubtful whether it would have exceeded 70 , unless some unusual change took place.

The sums of the average monthly catches of the more important species for the year 1939 divided by the corresponding average sums for the period 1930-4 inclusive are given below. In the second column are the figures for the best year divided by the worst year from I930 to 1939 inclusive.

\begin{tabular}{|c|c|c|}
\hline G. merlangus & $\begin{array}{c}\frac{1939}{\text { Av. } 1930-4} \\
0.08\end{array}$ & $\frac{\text { Best }}{\text { Worst }}$ \\
\hline G. minutus & $<0.13$ & $>40.3($ ('32/'39) \\
\hline Onos spp. & 0.08 & $29 \cdot 3$ ('30/'39) \\
\hline Arnoglossus sp. & 0.30 & II. 5 ('3I/'34) \\
\hline S. norvegicus & 0.04 & 43.0 (' $32 / ' 39$ \\
\hline P. limanda & 0.06 & 28.0 ('3I/'39) \\
\hline P. microcephalus & $<0.04$ & $>4 \mathrm{I} \cdot 0$ ('32/39) \\
\hline S. variegata & 0.05 & $32.5(32 / 39)$ \\
\hline Callionymus sp. & 0.07 & $15 \cdot 7$ ('30/'39) \\
\hline S. scombrus & 0.23 & II. 2 ('30/'35 \\
\hline Gobiid sp. & 0.05 & I I9.0 ('30/'3' \\
\hline
\end{tabular}

Of the species shown above all except Arnoglossus are normally practically absent by September, and it can be seen that the year 1939 has been the worst for all except three species during the period I930-9.

All species except Arnoglossus and Scomber were less than one-tenth of their average for the period $1930-4$.

If the number of young of summer spawners (57) be subtracted from the total young fish excluding clupeids (215), we are left with $\mathrm{I} 58$ for the remaining young fish most of which are the young of spring spawners. This is far and away the lowest number yet recorded and is nearly one-ninth of the 1395 specimens recorded in I93I. The results for the years $1930-9$ are summarized in Fig. 2.

It is of interest to record the unusual occurrence of young plaice in the catches in February and March. They have not been seen before during the long period of observations.

The evidence supplied by the plankton indicator species (Figs. 3 and 4) shows that until the end of the observations the conditions were very similar 
to those of 1938, although the numbers of Sagitta were on the whole even lower than in that year. In this respect the rather high proportion of $S$. elegans shown in the lower half of Fig. 3 is somewhat misleading since the numbers of both $S$. elegans and $S$. setosa were generally so small as to be almost insignificant. There were indications of a slight incursion of elegans water in January and February. No occurrence of unusual plankton organisms was recorded and Muggiaea atlantica was remarkably scarce. The total number of medusae of all species was even lower than in 1938.

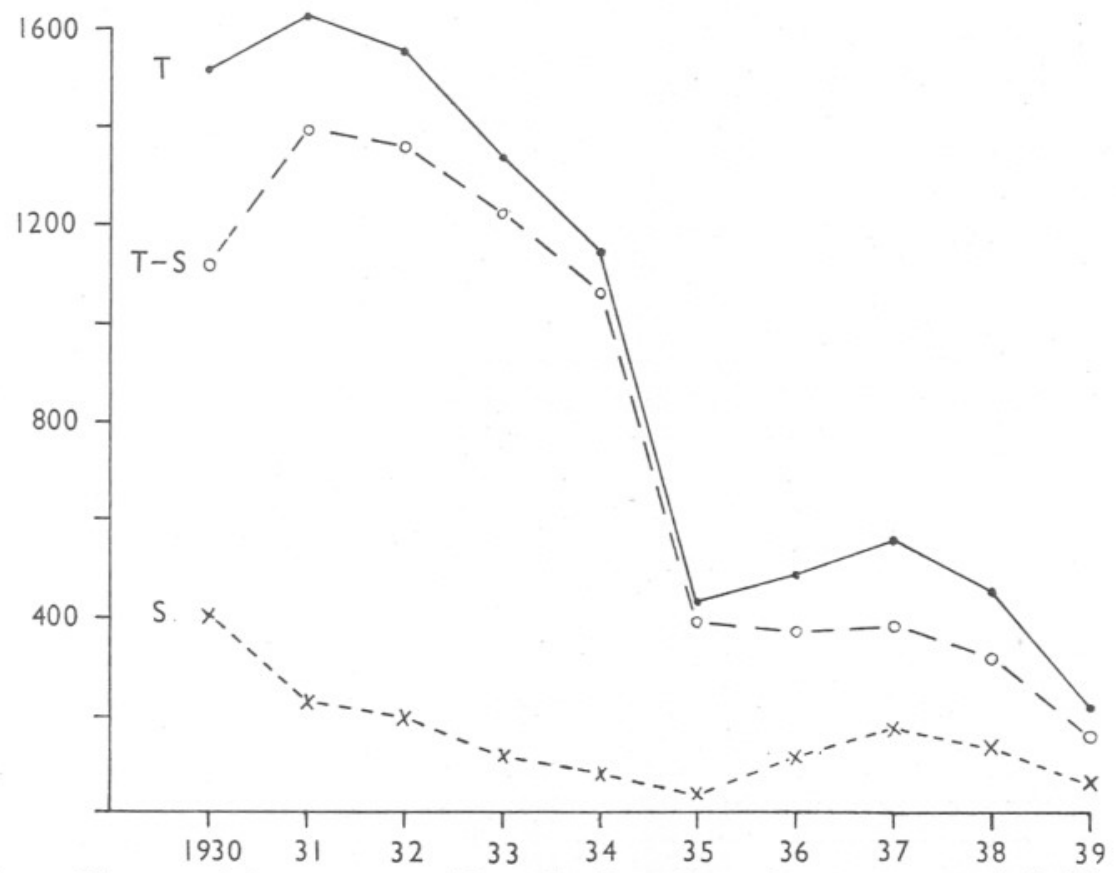

Fig. 2. The sums of the average monthly catches for each year from I930 to I 939 in half-hour oblique hauls with the $2 \mathrm{~m}$. ringtrawl for: $T$, total young fish (excluding clupeids); $S$, the young of summer spawners; and $T-\mathcal{S}$, total young fish less the young of summer spawners.

There were again large numbers of pilchard eggs, which were present from April until the end of August when collections ceased. Their approximate numbers in the catches in which they occurred were as follows: April I7 (40), 25 (1370); May I (370), 8 (380), I5 (3890), 23 (2070), 3I (8020); June 2 (2940), I9 (I9,480), 26 (I9,340); July 4 (4820), IO (680), I7 (I260), 24 (280), 3I (560); August I5 (I0), 2I (620), 28 (20).

\section{REFERENCE}

RUSSELl, F. S., 1939. On the seasonal abundance of young fish. VI. The year 1938. Fourn. Mar. Biol. Assoc., Vol. xxIII, pp. 38I-6. 

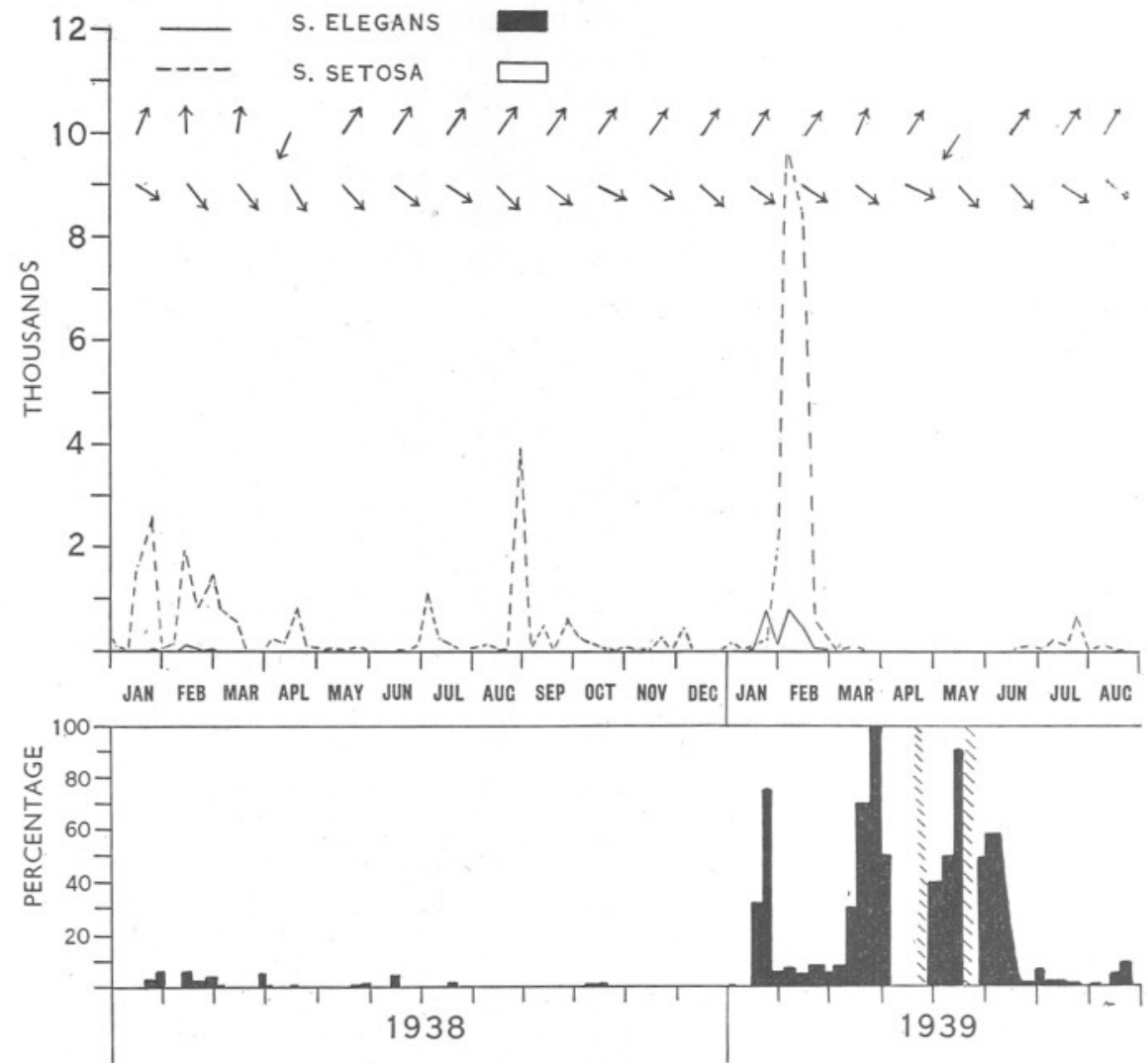

Fig. 3. Above, curves showing the actual abundance of S. elegans $(-)$ and $S$. setosa (-----) in half-hour oblique hauls with the $2 \mathrm{~m}$. ringtrawl during the period January I938 to August 1939. Below, the percentage composition of the Sagitta populations during the same period: $S$. elegans, black; $S$. setosa, white; no Sagitta, hatched. At the top of the diagram the arrows indicate the mean directions (true) of the flow of water past the Varne Lightship (above) and the Royal Sovereign Lightship (below) from data kindly supplied by Dr J. N. Carruthers. (Continued from Russell, I939, p. 383, Fig. 2.)

\section{Table I. Dates on which Collections were made, I939}

All 2 miles east of Eddystone unless otherwise stated

$\begin{array}{rrrrrrrr}\text { Jan. } & \text { Feb. } & \text { Mar. } & \text { Apr. } & \text { May } & \text { June } & \text { July } & \text { Aug. } \\ 2 & 8 & 6 & 3 & \text { I } & 2 & 4 & 8 \\ 9 & \text { I3 } & \text { I4 } & \text { I2 } & 8 & \text { I9 } & \text { I0 } & \text { I5 } \\ \text { I7 } & 2 \text { I } & 20 & \text { I7† } & \text { I5 } & 26 & \text { I7 } & 2 \text { I } \\ 24 & 27 & 27 & 25 & 23 & & 24 & 28 \\ 30^{\star} & & & & 3 \text { I } & & 3 I & \end{array}$

* Off Stoke Point.

† 6 miles W.S.W. of Rame Head. 


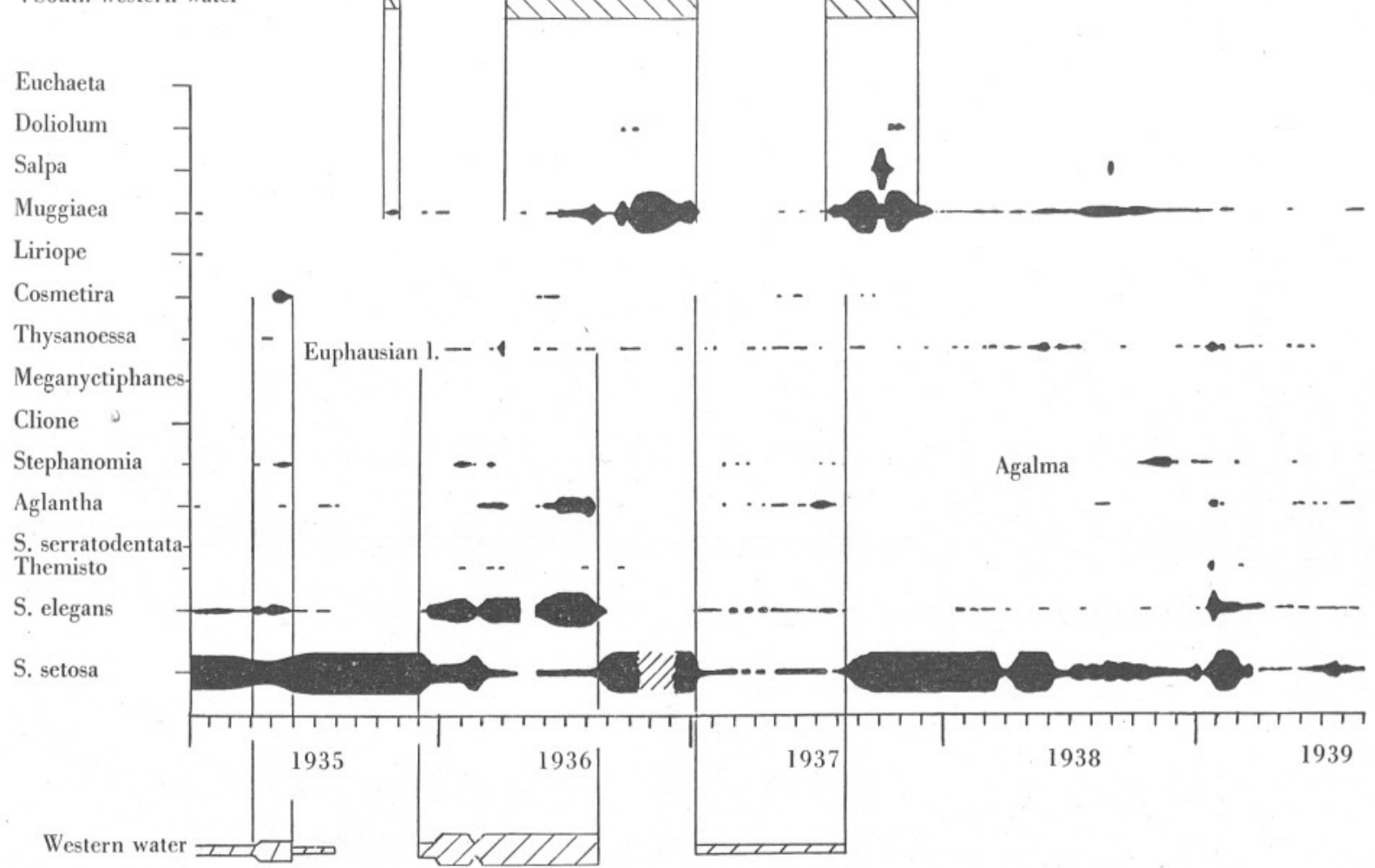

Fig. 4. Diagram showing the occurrence of the various plankton indicators in the collections off Plymouth during the years I935 to I939 inclusive. (Continued from Russell, I939, p. 384, Fig. 3.) The Muggiaea species were $M$. kochi up to January 1937, and thereafter $M$. atlantica; the salps were $S$. fusiformis, and the doliolids D. nationalis. 
Table II. Average Monthly Catches of Post-larvae per Half-hour

Oblique hauls with $2 \mathrm{~m}$. ringtrawl, 1939

Total young fish

Ditto, less Clupeids

All Clupeid spp.

Clupea harengus

Gadus pollachius

Gadus merlangus

Gadus minutus

Gadus luscus

Gadus callarius

Onos spp.

Molva molva

Merluccius merluccius

Raniceps raninus

Capros aper

Zeus faber

Arnoglossus sp.

Rhombus spp.

Scophthalmus norvegicus

Zeugopterus punctatus

Zeugopterus unimaculatus

Pleuronectes platessa

Pleuronectes limanda

Pleuronectes flesus

Pleuronectes microcephalus

Solea vulgaris

Solea variegata

Solea lascaris

Solea lutea

Serranus cabrilla

Caranx trachurus

Mullus surmulletus

Morone labrax

Ammodytes sp.

Ammodytes lanceolatus

Cepola rubescens

Callionymus $\mathrm{sp}$.

Labrus bergylta

Labrus mixtus

Ctenolabrus rupestris

Crenilabrus melops

Centrolabrus exoletus

Trachinus vipera

Scomber scombrus

Gobius spp.

Lebetus scorpioides

Blennius ocellaris

Blennius pholis

Blennius gattorugine

Chirolophis galerita

Agonus cataphractus

Trigla spp.

Cottus sp.

Liparis montagui

Lepadogaster bimaculatus Lophius piscatorius

Pipe fish

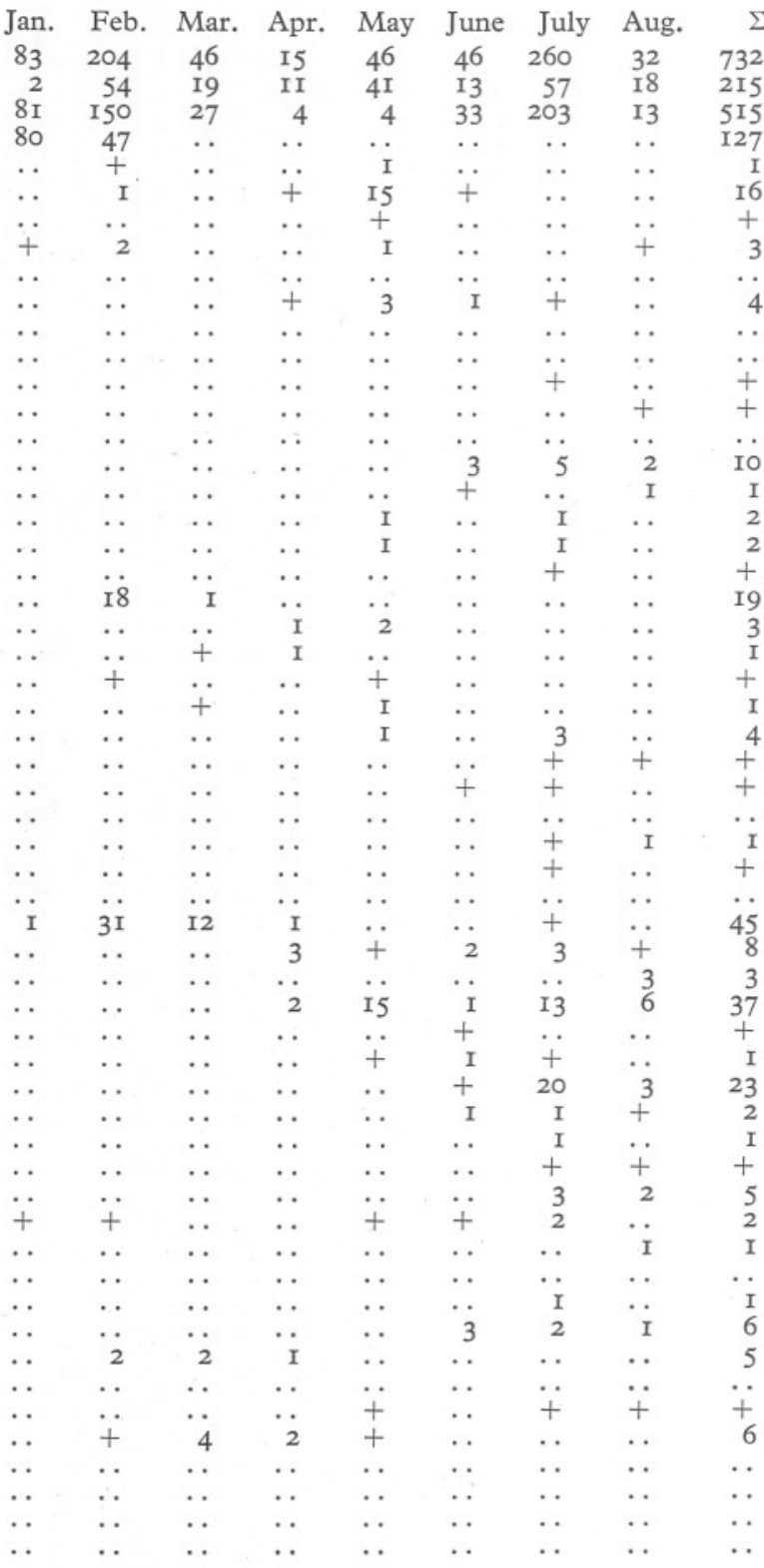

